\title{
THE INFLUENGe Of CINNAMON AND Ginger ON SERUM GluGOSE, TRIGLYCERIDES AND CHOLESTEROL FRACTIONS IN ALBINO INDUCED DIABETIC RATS
}

\author{
By \\ Hend M. Ali \\ Seham Ahmed Farrag
}

Home Economics Department, Nutrition Home Economics Department, Nutrition and Food Science, Faculty of Specific and Food Science, Faculty of Specific

Education, Assiut University, Assiut, A. Education, Assiut University, Assiut, A. R. Egypt.

R. Egypt.

Mohamed Anwar Abd AlAziz

Biochemistry Department, Faculty of Pharmacy, Al-Azhar Assiut University, Assiut, A. R. Egypt.

\section{Omima Ezzat Helmy}

Teacher first Home Economics in Assiut Secondary School for Girls, Assiut, A. R. Egypt.

\section{Research Gournal Specific Fducation \\ Faculty of Specific Education \\ gMansoura University}

ISSUE NO. 47, JULY. 2017

مجلة بحوث التربية النوعية - جامعة المنصورة

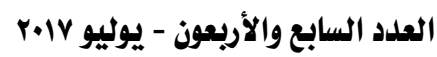




\title{
THE INFLUENGE OF CINNAMON AND GINGer ON SERUM GluGOSE, TRIGLYCERIDES AND CHOLESTEROL FRACTIONS IN ALBINO INDUCED DIABETIC RATS
}

\author{
Hend M. Ali* \\ Mohamed Anwar Abd AlAziz ${ }^{* * * *}$ \\ Seham Ahmed Farrag ${ }^{* * *}$ \\ Omima Ezzat Helmy ${ }^{* * * *}$

\section{Abstract}

The present investigation was carried out in an attempt to assess the effect of cinnamon and ginger on serum glucose, triglycerides and cholesterol fractions levels. Ninety male Sprague-Dawley rats weighting $120 \pm 5 \mathrm{~g}$ and divided into two groups. The first groups negative control group consisted of (10) rats fed on basal diet. The second main group consisted of (80) rats were injected intraperitoneal with alloxan monhydratein single dose $(150 \mathrm{mg} / \mathrm{kg})$ body weight and reclassified into eight sub groups (10 rats each). Subgroup (1), diabetic group was fed on basal diet only control positive group, subgroup (2), diabetic group was fed on basal diet plus 5\% cinnamon, subgroup (3), diabetic group was fed on basal diet plus $10 \%$ cinnamon, subgroup (4), diabetic group was fed on basal diet plus 5\% ginger, subgroup (5), diabetic group was fed on basal diet plus $10 \%$ ginger, subgroup (6), diabetic group was fed on basal diet plus $5 \%$ of both cinnamon and ginger, subgroup (7) diabetic group was fed on basal diet plus $10 \%$ of both cinnamon and ginger, subgroup (8) diabetic group was fed on basal diet plus (10 mg Atorvastatin $+30 \mathrm{mg}$ Gliclagide). The study was assigned for six weeks.

* Home Economics Department, Nutrition and Food Science, Faculty of Specific Education, Assiut University, Assiut, A. R. Egypt.

Home Economics Department, Nutrition and Food Science, Faculty of Specific Education, Assiut University, Assiut, A. R. Egypt.

${ }^{* * *}$ Biochemistry Department, Faculty of Pharmacy, Al-Azhar Assiut University, Assiut, A. R. Egypt.

Teacher first Home Economics in Assiut Secondary School for Girls, Assiut, A. R. Egypt. 
At the end of the experimental period rats were fasted over night before sacrificing, blood was collected then centrifuged to separate the serum. The results revealed that feeding rats on cinnamon, ginger and their combinations led to significant decreased in serum glucose, total cholesterol, triglycerides, LDL-cholesterol, VLDL-cholesterol and increased HDL-cholesterol.

The best improvement was subgroup (8) diabetic group was fed on basal diet plus (10 mg Atorvastatin $+30 \mathrm{mg}$ Gliclagide) followed by subgroup (7) diabetic group was fed on basal diet plus $10 \%$ of both cinnamon and ginger, then subgroups (3) and (5) namely diabetic group was fed on basal diet plus $10 \%$ cinnamon and diabetic group was fed on basal diet plus $10 \%$ ginger.

Therefore, this study recommended that the daily intake of cinnamon and ginger as a drink may be useful in the management of diabetes and improve serum levels of glucose and lipid profile.

Key words : Cinnamon, Ginger, Rats, Serum glucose, Lipid profile.

\section{Introduction}

Diabetes mellitus (DM) is a heterogeneous metabolic disorder, a high occurrence of disease in noted and the numbers of diabetic patients are gradually increasing, thus the disease constitutes a major health concern (Narendhirakannan et al., 2005 and Etuk, 2010).

According to the World Health Organization (WHO), there are approximately 347 million diabetics worldwide, the number of diabetics had been double in the last few years and diabetes death will increase by two thirds between 2008 and 2030 (WHO, 2012). Reasons for this rise include an increase in sedentary lifestyle, the consumption of energy-rich diet, obesity (Yajmk, 2001). Diabetes is the fourth or fifth leading cause of death in most high-income countries and there are substantial evidences that it is epidemic in many economically developing and newly industrialized countries (IDF, 2011).

Plants have always been an exemplary source of drugs, it's used in traditional medicine to treat diabetes mellitus represent a valuable alternative 
for the management of this disease, amongst such plants reported to have beneficial effects in the treatment of diabetes are spices such as cinnamon and ginger (Ugwuja et al., 2010; Gandhi and Sasikumar, 2012).

Cinnamon is a common spice used by different cultures around the world for several centuries. It is obtained from the inner bark of trees from the genus Cinnamomum, a tropical evergreen plant that has two main varieties; Cinnamomum zeylanicum (CZ) and Cinnamon cassia (CC) (also known as Cinnamomum aromaticum / Chinese cinnamon). In addition to its culinary uses, in native Ayurvedic medicine Cinnamon is considered a remedy for respiratory, digestive and gynecological ailments. Almost every part of the cinnamon tree including the bark, leaves, flowers, fruits and roots, has some medicinal or culinary use. The volatile oils obtained from the bark, leaf, and root barks vary significantly in chemical composition, which suggests that they might vary in their pharmacological effects. (Shen et al., 2002).

Ginger (Zingiber officinale, Roscoe Zingiberaceae) is one of the most widely consumed spices for the flavoring of food worldwide (Li et al., 2012). Ginger rhizome has been used in traditional herbal medicine. Ginger has enormous health promoting potential effects in number of ailments including degenerative disorders (arthritis and rheumatism), digestive health (indigestion and constipation), cardiovascular disorders (atherosclerosis and hypertension), diabetes mellitus and cancer. Also it has anti-inflammatory properties, which are beneficial in controlling the process of aging. Moreover, it has antimicrobial potential, which can help in treating infectious diseases and helminthiasis (Jiang et al., 2006; White, 2007; Ali et al., 2008 and Nicoll and Henein, 2009).

This investigation was carried out in an attempt to study the influence of cinnamon and ginger on serum glucose, triglycerides and cholesterol fractions in diabetic rats.

\section{Materials and Methods}

\section{Materials}

\section{Source of samples}

$5 \mathrm{~kg}$ of both cinnamon and ginger were obtained from Local Market, Assiut, Egypt, in March (2014). 


\section{Preparation of samples}

Preparation of (5\% and $10 \%)$ concentration of cinnamon and ginger (50 and $100 \mathrm{~g}$ ) were dissolved in $10 \mathrm{ml}$ toleween 80 (obtained from $\mathrm{El}$ Gomhorya Company) then diluted to $500 \mathrm{ml}$ with distilled water, then were shacked for 6 hours.

\section{Experimental animals}

One hundred and ten adult male white albino rats (Sprague dawley strain) weighing between (120 $\mathrm{g} \pm 5)$ were obtained from the animal house of the Faculty of Medicine, Assuit University. The animals were housed as groups in wire cages under the normal laboratory individually conditions and fed on the basal diet the rats were fed for a week as adaption period. Body weight gain and feed intake weighed weekly and at the end of the experimental feeding period.

\section{Basal diet and untreated diabetic diet}

The basal diet used is outlined in table (1)

Table (1): Constituents of the basal diet for $100 \mathrm{~g}$ diet.

\begin{tabular}{||l|c||}
\hline \multicolumn{1}{|c|}{ Item } & $\%$ \\
\hline \hline Corn starch & 67.8 \\
\hline Casein & 12.5 \\
\hline Corn oil & 10.0 \\
\hline Vitamins mixture & 1.0 \\
\hline Salt mixture & 3.5 \\
\hline Cellulose & 5.0 \\
\hline Choline chloride & 0.2 \\
\hline \hline & $100 \%$ \\
\hline \hline
\end{tabular}

Reeves et al., (1993).

\section{Chemicals}

Alloxan (Sigma, chemical company Lot 110H3367 for laboratory use only) was pruched from New Assiut Company, Toleween 80 was obtained from El Gomhorya Company and Atorvastatin + Gliclagide were 
obtained from local pharmacy, Assiut city, Assiut.

\section{Methods}

\section{Design of the experiment}

The rats were randomly allocated into (9) main Groups of (10) rats each. The number of animals in need during the course of the study was collectively (90) males the other rest (20) were used to overcome the loss in number of animals due to sudden death. Each rats was marked on the tail to differentiate between the animals in the (9) groups. Daily administrations were continued for two successive, periods (6) weeks each. In the first period group used as control and was fed on basal diets while the other eight groups were injected intraperitoneal with alloxan in a single does of 150 $\mathrm{mg} / \mathrm{kg}$ body weight (Pang et al,. 1985). The drug was dissolved in distilled water. In the eight groups the animals were tested for diabetes after five days the start of injection of alloxan . The animals were considered diabetic when its glucose level was $250 \mathrm{mg} / 100 \mathrm{ml}$ or more (normal blood glucose level was ranged between $90-120 \mathrm{mg} / 100 \mathrm{ml}$ )

After the onset of induced diabetic with alloxan, the animals were reclassified into the following groups fed on treated cinnamon and ginger as follows:

\section{Treated cinnamon and ginger groups}

Group (1) control group was fed on basal diet

Group (2) diabetic group was fed on basal diet.

Group (3) diabetic group was fed on basal diet plus 5\% cinnamon.

Group (4) diabetic group was fed on basal diet plus $10 \%$ cinnamon.

Group (5) diabetic group was fed on basal diet plus 5\% ginger.

Group (6) diabetic group was fed on basal diet plus $10 \%$ ginger.

Group (7) diabetic group was fed on basal diet plus $5 \%$ of both (cinnamon and ginger).

Group (8) diabetic group was fed on basal diet plus $10 \%$ of both (cinnamon and ginger).

Group (9) Diabetic group was fed on basal diet plus (Atorvastatin 10mg + Gliclagide 30mg). 
Ginger and cinnamon extract were given orally to the rats through a gastric tube daily at a dose of $4 \mathrm{ml} / \mathrm{kg}$ body weight.

\section{Blood sampling}

At the end of each experiment, rats were fasted overnight and anesthetized. Blood samples were collected from the retro-orbital plexus from all animals of each group into clean, dry and labeled tube. The tubes contained heparin $(10.0 \mathrm{IU} / \mathrm{ml})$ as anticoagulant. Blood was centrifuged (3500 r-p. m for $15 \mathrm{~min}$ ) to separate plasma. Which was tightly kept in sealed aliquot tubes at $20^{\circ} \mathrm{C}$ until biochemical assays.

\section{Biochemical methods}

Prepared samples (as mentioned in blood sampling) were used to study the following biochemical parameters using PHOTO Mech 301-D spectrophotometer (Optima).

\section{Determination of blood serum glucose}

Blood serum glucose level was analyzed calorimetric procedures kits developed by Diamond Diagnostics kits Cairo, Egypt using $550 \mathrm{n} / \mathrm{m}$. According to (Trinder, 2000).

\section{Determination of triglycerides}

Fully enzymatic determination of total triglycerides in serum was estimated spectrophtomtrically at $500 \eta \mathrm{m}$ according to the method of (Wahlefeld, 1974) of the enzymatic hydrolysis of triglycerides using Stanbio kits followed by determination of the liberated glycerol by colorimetry.

\section{Determination of serum total cholesterol}

Enzymatic determination of cholesterol was carried out according to the method of (Allian et al., 1974) using kits purchased from stanbio (Taxas, USA).

\section{Determination of High Density Lipoprotein (HDL-c) cholesterol}

The kits were provided from Stanbio, Lab., Inc. Texas. According to (Warnick et al., 1983). Low density Lipoprotein (LDL-c) cholesterol is precipitated from serum by magnesium chloride/ dextran sulfate reagent. 
High density lipoprotein (HDL-c) cholesterol is then determined in supernatant using cholesterol reagent.

\section{Determination of low Density lipoprotein $(L D L-c)$ cholesterol}

LDL was calculated by the difference between total cholesterol, HDL cholesterol and triglyceride according to as the method of (Friedewald et al., 1998) and was calculated using the following equation.

\section{Calculation:}

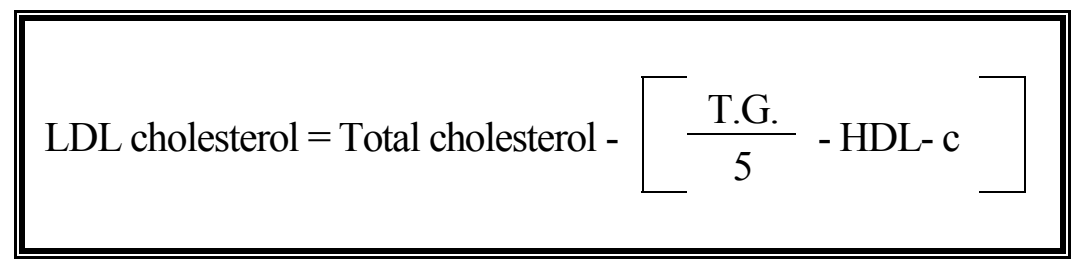

Calculation of Very Low Density Lipoproteins (VLDL-c) cholesterol

VLDL-c could be estimated reasonably well as TG concentrations divided by constant ( 5 for $\mathrm{mg} / \mathrm{dl}$ ), according to (Sniderman $\boldsymbol{e t}$ al., 2003; Bairaktari et al., 2005 and Gazi et al., 2006) as follow

\section{Calculation:}

$$
\text { VLDL-c mg/dl = Triglycerides } / 5
$$

\section{Statistical analysis}

Data was analyzed with analysis of variance (ANOVA) procedures using the MSTAT-C Statistical software package (Michigan State University, 1983). Where the F-test showed significant differences among means (Duncan) multiple range test (1955) was performed at the 0.05 level of probability to separate means. 
- The Influence of Cinnamon and Ginger on Serum Glucose, Triglycerides and Cholesterol Fractions

\section{Results and Discussion}

Table (2): Effect of different concentrations of cinnamon and ginger on blood serum glucose levels $(\mathrm{mg} / \mathrm{dl})$ in the different diabetic rat groups.

\begin{tabular}{|c|c|c|c|c|c|c|c|c|c|}
\hline \multirow{3}{*}{$\frac{n}{8}$} & \multirow[t]{2}{*}{ Control } & \multirow[t]{2}{*}{ Diabetic } & \multicolumn{2}{|c|}{ Cinnamon } & \multicolumn{2}{|c|}{ Ginger } & \multicolumn{2}{|c|}{$\begin{array}{c}\text { Cinnamon + } \\
\text { Ginger }\end{array}$} & \multirow[t]{2}{*}{ Drug } \\
\hline & & & $5 \%$ & $10 \%$ & $5 \%$ & $10 \%$ & $5 \%$ & $10 \%$ & \\
\hline & Group 1 & Group 2 & Group 3 & Group4 & Group5 & Group6 & Group7 & Group8 & Group9 \\
\hline 1 & $\begin{array}{c}108.4 \mathrm{~m} \\
\pm 3.12\end{array}$ & $\begin{array}{l}256.1^{\mathrm{cd}} \\
\pm 5.23\end{array}$ & $\begin{array}{l}251.5 \mathrm{~d} \\
\pm 3.54\end{array}$ & $\begin{array}{l}233.0 \mathrm{e} \\
\pm 6.21\end{array}$ & $\begin{array}{l}239.4 \mathrm{e} \\
\pm 4.51\end{array}$ & $\begin{array}{l}224.3 \mathrm{e} \\
\pm 3.45\end{array}$ & $\begin{array}{l}228.2 \mathrm{e} \\
\pm 4.51\end{array}$ & $\begin{array}{c}\text { 221.0ef } \\
\pm 3.56\end{array}$ & $\begin{array}{l}189.0 i \\
\pm 2.31\end{array}$ \\
\hline 2 & $\begin{array}{c}108.0 \mathrm{~m} \\
\pm 2.08\end{array}$ & $\begin{array}{l}266.2^{\mathrm{cd}} \\
\pm 4.15\end{array}$ & $\begin{array}{r}245.8 d \\
\pm 3.47\end{array}$ & $\begin{array}{l}225.5 \mathrm{ef} \\
\pm 2.93\end{array}$ & $\begin{array}{l}231.0 \mathrm{e} \\
\pm 2.60\end{array}$ & $\begin{array}{r}207.2 \mathrm{gh} \\
\pm 2.81 \\
\end{array}$ & $\begin{array}{r}214.4 \mathrm{~g} \\
\pm 3.04\end{array}$ & $\begin{array}{l}193.0 \mathrm{i} \\
\pm 3.04 \\
\end{array}$ & $\begin{array}{l}136.41 \\
\pm 6.41\end{array}$ \\
\hline 3 & $\begin{array}{c}100.6 \mathrm{~m} \\
\pm 1.96\end{array}$ & $\begin{array}{l}288.7^{\mathfrak{c}} \\
\pm 2.36\end{array}$ & $\begin{array}{c}\text { 238.1de } \\
\quad \pm 3.2\end{array}$ & $\begin{array}{c}216.8 \mathrm{fg} \\
\quad \pm 2.5\end{array}$ & $\begin{array}{c}222.3 \mathrm{ef} \\
\quad \pm 3.2\end{array}$ & $\begin{array}{c}204.5 \mathrm{gh} \\
\quad \pm 3.4\end{array}$ & $\begin{array}{c}205.7 \mathrm{gh} \\
\quad \pm 2.1\end{array}$ & $\begin{array}{c}185.7 i \\
\pm 1.6\end{array}$ & $\begin{array}{c}\text { 130.61 } \\
\pm 2.1\end{array}$ \\
\hline 4 & $\begin{array}{c}93.2 \mathrm{~m} \\
\pm 5.31\end{array}$ & $\begin{array}{l}311.1^{b c} \\
\pm 7.16\end{array}$ & $\begin{array}{c}230.3 \mathrm{e} \\
\pm 2.53\end{array}$ & $\begin{array}{c}208.2 \mathrm{Gh} \\
\pm 2.76\end{array}$ & $\begin{array}{c}216.2 \mathrm{fg} \\
\pm 3.23\end{array}$ & $\begin{array}{c}193.2 \mathrm{i} \\
\pm 2.6\end{array}$ & $\begin{array}{l}194.8 \mathrm{i} \\
\pm 2.22\end{array}$ & $\begin{array}{l}181.4 j \\
\pm 2.70\end{array}$ & $\begin{array}{l}128.91 \\
\pm 7.43\end{array}$ \\
\hline 5 & $\begin{array}{c}102.0 \mathrm{~m} \\
\pm 4.15\end{array}$ & $\begin{array}{r}343.0^{b} \\
\pm 9.11\end{array}$ & $\begin{array}{l}223.7 \mathrm{e} \\
\pm 6.91\end{array}$ & $\begin{array}{c}\text { 205.1gh } \\
\quad \pm 4.56\end{array}$ & $\begin{array}{c}209.8 \mathrm{hi} \\
\pm 2.35\end{array}$ & $\begin{array}{l}189.7 i \\
\pm 6.12\end{array}$ & $\begin{array}{l}183.6 j \\
\pm 3.15\end{array}$ & $\begin{array}{r}175.2 \mathrm{j} \\
\pm 5.23\end{array}$ & $\begin{array}{l}123.71 \\
\pm 3.21\end{array}$ \\
\hline 6 & $\begin{array}{c}106.9 \mathrm{~m} \\
\pm 6.10\end{array}$ & $\begin{array}{l}361.6^{a} \\
\pm 7.04\end{array}$ & $\begin{array}{c}\text { 213.0gh } \\
\pm 2.77\end{array}$ & $\begin{array}{l}197.2 \mathrm{i} \\
\pm 3.53\end{array}$ & $\begin{array}{c}\text { 203.0hi } \\
\pm 3.44\end{array}$ & $\begin{array}{l}182.8 j \\
\pm 2.32\end{array}$ & $\begin{array}{l}\mathbf{1 7 7 . 8 j} \\
\pm 4.03\end{array}$ & $\begin{array}{c}166.5 \mathrm{k} \\
\pm 3.61\end{array}$ & $\begin{array}{c}116.0 \mathrm{~m} \\
\pm 7.74\end{array}$ \\
\hline Mean & 103.23 G & $304.45^{A}$ & 233.73 B & 214.42 C & $220.28 \mathrm{C}$ & 200.28 D & $200.75 \mathrm{D}$ & $187.13 \mathrm{E}$ & $137.43 \mathrm{~F}$ \\
\hline
\end{tabular}

Values are presented as mean $\pm \mathrm{SD}$
For each group of rats $n=10$
S.E. Standard Error

Values followed by the same letter within the same column were not significantly different

F-test group $(\mathrm{G})=(\mathrm{A}) 178.6^{* *} \mathrm{P}<0.01$

F-test weeks $(\mathrm{W})=(\mathrm{B}) 23.6^{* *} \mathrm{P}<0.01$

F-test $(\mathrm{G} \times \mathrm{W})=(\mathrm{AB}) 32.9^{* *} \mathrm{P}<0.01$

\section{Effect of different concentrations of cinnamon and ginger on blood serum glucose levels (mg/dl) in the different diabetic rat groups}

The results given in the table (2) revealed that blood serum glucose levels showed significant differences among all the nine studied groups, all feeding weeks as well as interaction between studied groups at $(p<0.01)$.

The results showed that the mean blood serum glucose levels in diabetic 
rats groups treated with either cinnamon or ginger $(3,4,5,6,7$ and 8$)$ recording (233.73, 214.42, 220.28, 200.28, 200.75 and $187.13 \mathrm{mg} / \mathrm{dl})$; respectively were significantly decreased as compared to diabetic group (2) fed on basal diet without any treatment recording $304.45 \mathrm{mg} / \mathrm{dl}$. however, these levels were significantly increased than that of the control group of rats $(103.23 \mathrm{mg} / \mathrm{dl})$ while, group (9) standard fed on basal diet plus (Atorvastatin 10mg + Gliclagide 30mg) was recorded $137.43 \mathrm{mg} / \mathrm{dl}$ by the end of the feeding time of experiments (the $6^{\text {th }}$ week). These results of this present were in accordance with those reported by (Kamble and Rambhimaiah 2013), (Naserzadeh et al., 2014) and (Muhamed et al., 2016) in cinnamon while, the results content in ginger was agreement (Elshater et al., 2009), (Abdulrazaq et al., 2010), (Jafri et al., (2010), (Diaa and Al-Azhary 2011), (Manal and Anfenan 2014), (Khandouzia et al., 2015), (Hossain and Islam 2016).

These findings were in agreement with (Khan et al., 1990; Shalaby and Samar 2010 and Al-Jamal and Rasheed, 2010). hypoglycemic effect of cinnamon could be due to Insulin Potentiating Factor (IPF) that was isolated from cinnamon, which increased the activity of insulin 3 folds in glucose metabolism in the epididymal fat cells of rat. Later, this isolated factor (IPF) from cinnamon was termed as Methyl Hydroxy Chalcone Polymers (MHCP). They reported that MHCP was increased insulin dependent glucose metabolism many folds (more than 3 folds) when it was examined during in vitro studies (Broadhurst, et al., 2000). Others explained that MHCP caused fat cells more responsive to insulin through activating the insulin-receptor-kinase enzyme that causes binding of insulin to the cells and inhibiting insulin-receptorphosphatase enzyme that blocks this binding process thereby MHCP leads to maximal phosphorylation of the insulin receptor, which is associated with increased insulin sensitivity and enhances glycogen synthase activity (Khan et al., 2003; Anderson $\boldsymbol{e t}$ al., 2006; Kim et al., 2006 and Nadia et al., 2011). (Ugochukw and Babady, 2003) mentioned that cinnamon increases the production of Glucose-6-Phosphate Dehydrogenase (G-6-PDH) in the liver in which G-6PDH leads to reduce glucose transporting by pentose phosphate pathway (pentose shunt) and storage of glucose as a glycogen in the liver. Cinnamon 
was mentioned in other study to activate the function glucokinase enzyme which in turn stimulates Glucose Transporter-4 (GLUT4) for entering of glucose to the hepatic cells (glycogenesis) and adipocytes lead to increase in glycogen storage available for energy production.

(Ramudu et al., 2011 and Chakraborty et al., 2012) revealed that ginger has been shown to modulate insulin release in rat pancreatic $\beta$-cells, thus enhanced plasma insulin levels in conjunction with lowered blood glucose, this may be due to 6-gingerol, which is considered an active component in ginger, so showed a protective effect on pancreatic $\beta$-cells and restored the plasma insulin level.

(White, 2007) reported that ginger is contain over 20 phenolic compounds, these compound displays diverse biological activities such as antioxidant, antidiabetic, hypoglycemic and a lose reductase inhibitory properties.

Kar et al., (1999) reported that, the inorganic part of a medicinal plant contains mainly mineral elements, which are responsible for the hypoglycemic activity. In support of this view, a number of essential minerals (Ca, Zn, K, Mn and $\mathrm{Cr}$ ), are known to be associated with the mechanisms of insulin release and its activity in different animals and in human beings (Castro, 1998). 
Table (3): Effect of different concentrations of cinnamon and ginger on serum triglycerides levels $(\mathrm{mg} / \mathrm{dl})$ in the different diabetic rat groups.

\begin{tabular}{|c|c|c|c|c|c|c|c|c|c|}
\hline \multirow{3}{*}{ 苋 } & \multirow{2}{*}{ 㝘 } & \multirow{2}{*}{ 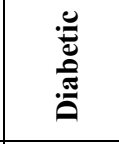 } & \multicolumn{2}{|c|}{ Cinnamon } & \multicolumn{2}{|c|}{ Ginger } & \multicolumn{2}{|c|}{$\begin{array}{c}\text { Cinnamon+ } \\
\text { Ginger }\end{array}$} & \multirow[t]{2}{*}{ Drug } \\
\hline & & & $5 \%$ & $10 \%$ & $5 \%$ & $10 \%$ & $5 \%$ & $10 \%$ & \\
\hline & $\begin{array}{c}\text { Group } \\
1\end{array}$ & $\begin{array}{c}\text { Group } \\
2\end{array}$ & $\begin{array}{c}\text { Group } \\
3\end{array}$ & $\begin{array}{c}\text { Group } \\
4\end{array}$ & $\begin{array}{c}\text { Group } \\
5\end{array}$ & $\begin{array}{c}\text { Group } \\
6\end{array}$ & $\begin{array}{c}\text { Group } \\
7\end{array}$ & $\begin{array}{c}\text { Group } \\
8\end{array}$ & $\begin{array}{c}\text { Group } \\
9\end{array}$ \\
\hline 1 & $\begin{array}{c}110.1 q \\
\pm 3.9\end{array}$ & $\begin{array}{c}233.8 \mathrm{a} \\
\pm 4.6\end{array}$ & $\begin{array}{c}227.7 \mathrm{~cd} \\
\pm 4.1\end{array}$ & $\begin{array}{c}216.7 \mathrm{de} \\
\pm 3.2\end{array}$ & $\begin{array}{c}217.8 \mathrm{ef} \\
\pm 3.4\end{array}$ & $\begin{array}{c}205.6 \mathrm{ef} \\
\pm 3.2\end{array}$ & $\begin{array}{c}\text { 199.3fgh } \\
\pm 2.1\end{array}$ & $\begin{array}{c}179.7 \mathbf{i j} \\
\pm 2.3\end{array}$ & $\begin{array}{c}156.7 \mathrm{kl} \\
\pm 1.6\end{array}$ \\
\hline 2 & $\begin{array}{c}110.0 \mathrm{q} \\
\pm 4.2\end{array}$ & $\begin{array}{c}244.9 \mathrm{c} \\
\pm 3.3\end{array}$ & $\begin{array}{c}223.2 \mathrm{~cd} \\
\pm 4.3\end{array}$ & $\begin{array}{c}210.1 \text { ef } \\
\pm 3.9\end{array}$ & $\begin{array}{c}213.8 \mathrm{de} \\
\pm 4.2\end{array}$ & $\begin{array}{c}\text { 202.2 efg } \\
\pm 3.0\end{array}$ & $\begin{array}{c}190.9 \mathrm{hi} \\
\pm 5.9\end{array}$ & $\begin{array}{c}163.4 \mathrm{k} \\
\pm 5.5\end{array}$ & $\begin{array}{c}147.2 \mathrm{mn} \\
\pm 3.9\end{array}$ \\
\hline 3 & $\begin{array}{c}110.3 q \\
\pm 1.6\end{array}$ & $\begin{array}{c}238.7 \mathrm{~b} \\
\pm 2.6 \\
\end{array}$ & $\begin{array}{c}216.8 \mathrm{e} \\
\pm 1.8 \\
\end{array}$ & $\begin{array}{c}204.6 \text { ef } \\
\pm 2.1 \\
\end{array}$ & $\begin{array}{c}207.3 \mathrm{ef} \\
\pm 3.1 \\
\end{array}$ & $\begin{array}{c}196.7 \mathrm{gh} \\
\pm 1.6 \\
\end{array}$ & $\begin{array}{c}182.3 \mathrm{hi} \\
\pm 2.3 \\
\end{array}$ & $\begin{array}{c}156.1 \mathrm{k} \\
\pm 2.3 \\
\end{array}$ & $\begin{array}{c}133.9 \mathrm{n} \\
\pm 2.3 \\
\end{array}$ \\
\hline 4 & $\begin{array}{c}110.6 q \\
\pm 6.6 \\
\end{array}$ & $\begin{array}{c}252.7 \mathrm{~b} \\
\pm 3.6 \\
\end{array}$ & $\begin{array}{c}211.0 \mathrm{ef} \\
\pm 3.8 \\
\end{array}$ & $\begin{array}{c}196.3 \mathrm{gh} \\
\pm 4.0 \\
\end{array}$ & $\begin{array}{c}\text { 200.2fgh } \\
\pm 3.4 \\
\end{array}$ & $\begin{array}{c}189.4 \mathrm{hi} \\
\pm 3.7 \\
\end{array}$ & $\begin{array}{c}178.9 \mathrm{ij} \\
\pm 7.7 \\
\end{array}$ & $\begin{array}{c}150.7 \mathrm{kl} \\
\pm 4.2 \\
\end{array}$ & $\begin{array}{c}121.1 \mathrm{pq} \\
\pm 3.4 \\
\end{array}$ \\
\hline 5 & $\begin{array}{c}110.6 q \\
\pm 2.6 \\
\end{array}$ & $\begin{array}{c}254.5 \mathrm{a} \\
\pm 5.1 \\
\end{array}$ & $\begin{array}{c}\text { 200.9fgh } \\
\pm 4.1 \\
\end{array}$ & $\begin{array}{c}185.7 \mathrm{hi} \\
\pm 1.9\end{array}$ & $\begin{array}{c}191.8 g h \\
\pm 2.1 \\
\end{array}$ & $\begin{array}{c}173.4 \mathrm{k} \\
\pm 2.1 \\
\end{array}$ & $\begin{array}{c}156.8 \mathrm{kl} \\
\pm 1.8 \\
\end{array}$ & $\begin{array}{c}142.7 \mathrm{mn} \\
\pm 2.3 \\
\end{array}$ & $\begin{array}{c}118.9 p q \\
\pm 1.7 \\
\end{array}$ \\
\hline 6 & $\begin{array}{c}110.3 q \\
\pm 6.7 \\
\end{array}$ & $\begin{array}{c}256.0 \mathrm{a} \\
\pm 3.0 \\
\end{array}$ & $\begin{array}{c}192.7 \mathrm{gh} \\
\pm 3.5 \\
\end{array}$ & $\begin{array}{c}170.8 \mathrm{jk} \\
\pm 6.7 \\
\end{array}$ & $\begin{array}{c}179.7 \mathrm{ij} \\
\pm 4.7 \\
\end{array}$ & $\begin{array}{c}154.2 \mathrm{Im} \\
\pm 7.1 \\
\end{array}$ & $\begin{array}{c}140.8 \mathrm{mn} \\
\pm 6.9\end{array}$ & $\begin{array}{c}130.7 \mathrm{pq} \\
\pm 5.3 \\
\end{array}$ & $\begin{array}{c}115.2 q \\
\pm 3.3 \\
\end{array}$ \\
\hline ean[ & $108.7 \mathrm{H}$ & 246.8 A & 212.1 B & $197.4 \mathrm{C}$ & $200.4 \mathrm{C}$ & 186.9 D & $174.8 \mathrm{E}$ & $154.2 \mathrm{~F}$ & $131.2 \mathrm{G}$ \\
\hline
\end{tabular}

Values are presented as mean $\pm \mathrm{SD}$

For each group of rats $\mathrm{n}=10$

S.E. Standard Error

Values followed by the same letter with in the same column were not significantly different

F-test group $(\mathrm{G})=(\mathrm{A}) 112.6^{* *} \mathrm{P}<0.01$

F-test weeks $(\mathrm{W})=(\mathrm{B}) 33.25^{* *} \mathrm{P}<0.01$

F-test $(\mathrm{G} \times \mathrm{W})=(\mathrm{AB}) 5.09 * * \quad \mathrm{P}<0.01$

Effect of different concentrations of cinnamon and ginger on serum triglycerides levels $(\mathrm{mg} / \mathrm{dl})$ in the different diabetic rat groups

The results given in the table (3) revealed that serum triglycerides levels showed significant differences among all the nine studied groups, all feeding weeks as well as interaction between studied groups at $(p<0.01)$.

The results of the study showed that the mean triglyceride levels in diabetic rats groups treated with either cinnamon and ginger (3,4,5,6,7 and 8) recording $(212.1,197.4,200.4,186.9,174.8$ and $154.2 \mathrm{mg} / \mathrm{dl})$; respectively were significantly decreased as compared to diabetic group (2) fed on basal diet 
without any treatment recording $246.8 \mathrm{mg} / \mathrm{dl}$. However, these levels were significantly increased than that of the control group of rats $(108.7 \mathrm{mg} / \mathrm{dl})$. While, group (9) standard fed on basal diet plus (Atorvastatin $10 \mathrm{mg}+$ Gliclagide $30 \mathrm{mg}$ ) was recorded $131.2 \mathrm{mg} / \mathrm{dl}$ by the end of the feeding time of experiments (the $6^{\text {th }}$ week).

These results are in agreement with (Gullapalli et al., (2013), (Khogali et al., 2014) and (Amal et al., 2016) in cinnamon while, the results content in ginger was agreement with (Ramudu et al., 2011), (Hussein, 2012), (Maisa et al., 2016) and (El-Sayed and Reham 2016). 
Table (4): Effect of different concentrations of cinnamon and ginger on serum total cholesterol levels $(\mathrm{mg} / \mathrm{dl})$ in the different diabetic rat groups.

\begin{tabular}{|c|c|c|c|c|c|c|c|c|c|}
\hline \multirow{3}{*}{$\frac{2}{8}$} & \multirow{2}{*}{ ō } & \multirow{2}{*}{$\begin{array}{l}.0 \\
\frac{0}{0} \\
\frac{0}{0} \\
.00\end{array}$} & \multicolumn{2}{|c|}{ Cinnamon } & \multicolumn{2}{|c|}{ Ginger } & \multicolumn{2}{|c|}{$\begin{array}{c}\text { Cinnamon + } \\
\text { Ginger }\end{array}$} & \multirow[t]{2}{*}{ Drug } \\
\hline & & & $5 \%$ & $10 \%$ & $5 \%$ & $10 \%$ & $5 \%$ & $10 \%$ & \\
\hline & Group 1 & Group 2 & Group 3 & Group 4 & Group 5 & Group 6 & Group 7 & Group 8 & Group 9 \\
\hline 1 & $\begin{array}{c}154.7 p \\
\pm 1.96 \\
\end{array}$ & $\begin{array}{c}235.4 c \\
\pm 4.1 \\
\end{array}$ & $\begin{array}{l}230.6 \mathrm{c} \\
\pm 4.23\end{array}$ & $\begin{array}{l}227.3 c \\
\pm 3.12 \\
\end{array}$ & $\begin{array}{l}229.9 c \\
\pm 2.88\end{array}$ & $\begin{array}{c}\text { 218.6def } \\
\pm 3.12 \\
\end{array}$ & $\begin{array}{c}\text { 221.2def } \\
\pm 1.85\end{array}$ & $\begin{array}{c}212.3 f g h \\
\pm 2.13\end{array}$ & $\begin{array}{c}193.01 m n \\
\pm 1.96\end{array}$ \\
\hline 2 & $\begin{array}{c}139.8 q \\
\pm 6.1\end{array}$ & $\begin{array}{c}238.0 b \\
\pm 2.1\end{array}$ & $\begin{array}{c}222.7 \mathrm{~cd} \\
\pm 3.7\end{array}$ & $\begin{array}{c}215.9 \mathrm{efg} \\
\pm 3.2\end{array}$ & $\begin{array}{c}217.8 \mathrm{def} \\
\pm 5.3\end{array}$ & $\begin{array}{c}206.6 \mathrm{ijk} \\
\pm 4.2\end{array}$ & $\begin{array}{c}207.7 \mathrm{hij} \\
\pm 3.9\end{array}$ & $\begin{array}{c}191.5 \operatorname{lmn} \\
\pm 4.0\end{array}$ & $\begin{array}{c}163.6 p \\
\pm 2.9\end{array}$ \\
\hline 3 & $\begin{array}{c}136.6 q \\
\pm 4.1\end{array}$ & $\begin{array}{c}245.1 b \\
\pm 4.4\end{array}$ & $\begin{array}{c}219.2 \mathrm{de} \\
\pm 2.1\end{array}$ & $\begin{array}{c}\text { 212.0ghi } \\
\pm 3.1\end{array}$ & $\begin{array}{c}213.6 \mathrm{ghi} \\
\pm 4.1\end{array}$ & $\begin{array}{c}201.3 \mathrm{jkl} \\
\pm 2.1\end{array}$ & $\begin{array}{c}200.7 \mathbf{j k l} \\
\pm 2.3\end{array}$ & $\begin{array}{c}180.7 n \\
\pm 2.1\end{array}$ & $\begin{array}{c}154.5 p \\
\pm 2.1\end{array}$ \\
\hline 4 & $\begin{array}{c}138.7 q \\
\pm 5.3\end{array}$ & $\begin{array}{c}256.7 b \\
\pm 3.89 \\
\end{array}$ & $\begin{array}{c}218.7 \mathrm{de} \\
\pm 3.3\end{array}$ & $\begin{array}{c}210.2 \mathrm{hij} \\
\pm 3.6\end{array}$ & $\begin{array}{c}211.9 \text { fgh } \\
\pm 4.8\end{array}$ & $\begin{array}{c}199.8 \mathrm{jkl} \\
\pm 3.8\end{array}$ & $\begin{array}{c}196.8 \mathrm{klm} \\
\pm 3.9\end{array}$ & $\begin{array}{c}183.2 \mathrm{n} \\
\pm 4.2\end{array}$ & $\begin{array}{c}146.9 q \\
\pm 3.0\end{array}$ \\
\hline 5 & $\begin{array}{c}145.6 \mathrm{p} \\
\pm 1.86\end{array}$ & $\begin{array}{c}280.5 \mathrm{a} \\
\pm 5.9\end{array}$ & $\begin{array}{c}\text { 213.6ghi } \\
\pm 3.12\end{array}$ & $\begin{array}{c}204.2 \mathrm{jk} \\
\pm 2.65\end{array}$ & $\begin{array}{c}209.1 \mathrm{hij} \\
\pm 3.56 \\
\end{array}$ & \begin{tabular}{|c|}
$192.31 \mathrm{mn}$ \\
\pm 3.11 \\
\end{tabular} & $\begin{array}{c}190.11 \mathrm{mn} \\
\pm 2.21\end{array}$ & $\begin{array}{c}178.6 \mathrm{no} \\
\pm 1.26 \\
\end{array}$ & $\begin{array}{c}139.6 q \\
\pm 1.56 \\
\end{array}$ \\
\hline 6 & $\begin{array}{c}157.0 \mathrm{p} \\
\pm 8.5\end{array}$ & $\begin{array}{c}282.6 a \\
\pm 2.13\end{array}$ & $\begin{array}{c}211.2 \mathrm{ghi} \\
\pm 3.3\end{array}$ & $\begin{array}{c}200.8 \mathrm{jkl} \\
\pm 4.0\end{array}$ & $\begin{array}{c}204.3 \mathrm{ijk} \\
\pm 4.7\end{array}$ & $\begin{array}{c}188.4 \mathrm{mn} \\
\pm 3.9 \\
\end{array}$ & $\begin{array}{c}187.8 \mathrm{mn} \\
\pm 3.5\end{array}$ & $\begin{array}{c}173.40 \\
\pm 4.1\end{array}$ & $\begin{array}{c}129.3 \mathrm{r} \\
\pm 3.3\end{array}$ \\
\hline Mean & $145.4 \mathrm{E}$ & $255.6 \mathrm{~A}$ & 220.0B & 211.7BC & 214.4B & $201.2 \mathrm{C}$ & $200.7 \mathrm{C}$ & 186.6D & $146.8 \mathrm{E}$ \\
\hline
\end{tabular}

Values are presented as mean $\pm \mathrm{SD}$

For each group of rats $n=10$

S.E. Standard Error

Values followed by the same letter with in the same column were not significantly different

F-test group $(\mathrm{G})=(\mathrm{A}) 106.7^{* *} \mathrm{P}<0.01$

F-test weeks $(\mathrm{W})=(\mathrm{B}) 80.45^{* *} \mathrm{P}<0.01$

F-test $(\mathrm{G} \times \mathrm{W})=(\mathrm{AB}) 11.98^{* *} \mathrm{P}<0.01$

\section{Effect of different concentrations of cinnamon and ginger on serum total} cholesterol levels $(\mathrm{mg} / \mathrm{dl})$ in the different diabetic rat groups

The results given in the table (4) revealed that total cholesterol levels showed significant differences among all the nine studied groups, all feeding weeks as well as interaction between studied groups and feeding weeks at $(\mathrm{p}<0.01)$.

The results showed that the mean total cholesterol levels in diabetic rats groups treated with either cinnamon or ginger $(3,4,5,6,7$ and 8) recording $(220.0,211.7,214.4,201.2,200.7$ and $186.6 \mathrm{mg} / \mathrm{dl})$; respectively 
were significantly decreased as compared to diabetic group (2) fed on basal diet without any treatment recording $255.6 \mathrm{mg} / \mathrm{dl}$. However, these levels were significantly increased than that of the control group of rats (145.4 $\mathrm{mg} / \mathrm{dl}$ ). While, group (9) standard fed on basal diet plus (Atorvastatin 10mg + Gliclagide 30mg) was recorded $146.8 \mathrm{mg} / \mathrm{dl}$ by the end of the feeding time of experiments (the $6^{\text {th }}$ week). These results are in agreement with (Srinivasan and Sambaiah 1991) reported that feeding rats with ginger significantly elevated the activity of hepatic cholesterol 7-alpha-hydroxylase which is a rate-limiting enzyme in the biosynthesis of the bile acids and stimulates the conversion of cholesterol to bile acids leading to the excretion of cholesterol from the body. In support of this view, the study of (Bhandari $\boldsymbol{e} t$ al., $\mathbf{1 9 9 8}^{\mathrm{b}}$ ) revealed that posttreatment with ginger extract to the cholesterolfed rabbits for 70 days resulted in less marked hyperlipidaemic when compared to the pathogenic rats. Moreover, the marked hyperlipidemia that characterizes the diabetic state may therefore be regarded because of the uninhibited actions of lipolytic hormones on the fat depots due to the absence of insulin (Goodman and Gilman 1985).

(Thomson et al., 2002 and Verma et al., 2004) stated that ginger significantly lowered serum total cholesterol, LDL, VLDL and triglycerides and raised HDL., their results to the reducing effect of ginger acted on cholesterol biosynthesis in the liver and may stimulate cholesterol's conversion to bile acid and increase its fecal excretion. 
Table (5): Effect of different concentrations of cinnamon and ginger on the serum High Density Lipoprotein (HDL) levels (mg/dl) in the different diabetic rat groups.

\begin{tabular}{|c|c|c|c|c|c|c|c|c|c|}
\hline \multirow{4}{*}{$\frac{\pi}{8}$} & \multirow{2}{*}{$\begin{array}{l}\bar{D} \\
\ddot{\Xi} \\
\dot{\theta}\end{array}$} & \multirow{2}{*}{ 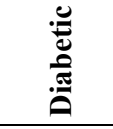 } & \multicolumn{2}{|c|}{ Cinnamon } & \multicolumn{2}{|c|}{ Ginger } & \multicolumn{2}{|c|}{ Cinnamon + Ginger } & \multirow{2}{*}{ Drug } \\
\hline & & & $5 \%$ & $10 \%$ & $5 \%$ & $10 \%$ & $5 \%$ & $10 \%$ & \\
\hline & Group & Group & Group & Group & Group & Group & Group & Group & Group \\
\hline & 1 & 2 & 3 & 4 & 5 & 6 & 7 & 8 & 9 \\
\hline \multirow{2}{*}{1} & 39.10a & $21.90 \mathrm{kl}$ & $23.80 n$ & $26.60 \mathrm{~m}$ & $26.90 \mathrm{~m}$ & $28.20 j$ & $28.00 j$ & 29.80ij & 30.20gh \\
\hline & $\pm \mathbf{0 . 6 5}$ & \pm 1.21 & $\pm \mathbf{0 . 7 9}$ & \pm 1.12 & \pm 1.13 & \pm 1.23 & $\pm \mathbf{0 . 6 5}$ & \pm 0.65 & $\pm \mathbf{0 . 8 9}$ \\
\hline \multirow{2}{*}{2} & $39.00 a$ & 21.700 & $24.60 n$ & 27.501m & $27.80 \mathrm{kl}$ & 29.70hij & 29.40ij & 30.90gh & 32.40ef \\
\hline & \pm 0.75 & $\pm \mathbf{0 . 6 7}$ & \pm 0.65 & \pm 0.72 & \pm 0.59 & $\pm \mathbf{0 . 4 7}$ & $\pm \mathbf{0 . 5 2}$ & \pm 0.48 & \pm 0.40 \\
\hline \multirow{2}{*}{3} & $39.70 a$ & 20.95p & $25.01 n$ & 28.20ij & $28.20 \mathrm{ij}$ & 30.00gh & 30.10gh & $31.20 \mathrm{fg}$ & $33.00 \mathrm{~cd}$ \\
\hline & \pm 0.96 & $\pm \mathbf{0 . 8 7}$ & \pm 0.73 & $\pm \mathbf{0 . 7 8}$ & $\pm \mathbf{0 . 6 3}$ & \pm 0.65 & \pm 0.69 & \pm 0.69 & \pm 0.66 \\
\hline \multirow{2}{*}{4} & $39.20 \mathrm{a}$ & $20.20 p$ & $26.50 \mathrm{~m}$ & 29.50ij & 29.30ij & $31.20 f g$ & 30.60ghi & 32.40ef & $33.90 \mathrm{~cd}$ \\
\hline & $\pm \mathbf{0 . 8 0}$ & $\pm \mathbf{0 . 7 0}$ & \pm 0.76 & \pm 0.56 & \pm 0.56 & $\pm \mathbf{0 . 3 6}$ & $\pm \mathbf{0 . 3 7}$ & $\pm \mathbf{0 . 4 0}$ & \pm 0.55 \\
\hline \multirow{2}{*}{5} & $39.20 \mathrm{a}$ & $18.90 q$ & $27.201 \mathrm{~m}$ & $30.10 \mathrm{gh}$ & $30.50 \mathrm{gh}$ & 32.30de & 31.80fg & $33.60 \mathrm{~cd}$ & 35.30b \\
\hline & \pm 0.81 & \pm 0.51 & \pm 0.98 & $\pm \mathbf{0 . 8 8}$ & \pm 0.92 & $\pm \mathbf{0 . 7 7}$ & $\pm \mathbf{0 . 3 8}$ & \pm 0.71 & $\pm \mathbf{0 . 7 8}$ \\
\hline \multirow{2}{*}{6} & $39.20 \mathrm{a}$ & $18.70 q$ & 29.00jk & 30.90gh & 31.30fg & 32.90de & 32.50ef & $34.20 \mathrm{c}$ & $36.20 \mathrm{~b}$ \\
\hline & \pm 0.80 & $\pm \mathbf{0 . 4 7}$ & $\pm \mathbf{0 . 6 7}$ & $\pm \mathbf{0 . 5 7}$ & $\pm \mathbf{0 . 3 7}$ & \pm 0.28 & $\pm \mathbf{0 . 4 3}$ & \pm 0.36 & \pm 0.55 \\
\hline Mean & $39.33 \mathrm{~A}$ & $21.39 \mathrm{~F}$ & $26.03 \mathrm{E}$ & $28.80 \mathrm{D}$ & 29.00 D & $30.72 \mathrm{C}$ & $30.50 \mathrm{C}$ & 32.02 B & $33.50 \mathrm{~B}$ \\
\hline
\end{tabular}

Values are presented as mean $\pm \mathrm{SD}$

For each group of rats $\mathrm{n}=10$

S.E. Standard Error

Values followed by the same letter with in the same column were not significantly different.

F-test group $(\mathrm{G})=(\mathrm{A}) 156.4 * * \mathrm{P}<0.01$

F-test weeks $(\mathrm{W})=(\mathrm{B}) 55.35 * * \mathrm{P}<0.01$

F-test $(\mathrm{G} \times \mathrm{W})=(\mathrm{AB}) 6.343^{* *} \mathrm{P}<0.01$

Effect of different concentrations of cinnamon and ginger on the serum High Density Lipoprotein (HDL) levels (mg/dl) in the different diabetic rat groups

The results given in the table (5) revealed that High Density Lipoprotein (HDL) levels showed significant differences among all the nine studied groups, all feeding weeks as well as interaction between studied groups and feeding weeks at $(\mathrm{p}<0.01)$.

The results showed that the mean HDL levels in diabetic rats groups 
treated with either cinnamon or ginger $(3,4,5,6,7$ and 8$)$ recording (26.03, $28.80,29.00,30.72,30.50$ and $32.02 \mathrm{mg} / \mathrm{dl})$; respectively were significantly increased as compared to diabetic group (2) fed on basal diet without any treatment recording $21.39 \mathrm{mg} / \mathrm{dl}$. However, these levels were significantly decreased than that of the control group of rats $(39.33 \mathrm{mg} / \mathrm{dl})$. While, group (9) standard fed on basal diet plus (Atorvastatin $10 \mathrm{mg}$ + Gliclagide $30 \mathrm{mg}$ ) was recorded $33.50 \mathrm{mg} / \mathrm{dl}$ by the end of the feeding time of experiments (the $6^{\text {th }}$ week).

These data are in agreement with (Hussein, 2012) reported that the effect of daily intraperitoneal injection of ginger extract for four weeks on some biochemical parameters (serum cholesterol, HDL, LDL) and kidney functions (urea, uric acid, creatinine), were significant decrease $(\mathrm{p}<0.01)$, while (HDL) appeared significant increase when compared with control group antioxidative properties of ginger represent the main way for protecting vascular wall against oxidative stress induced in diabetic cholesterol-fed animals. This effect may work independently of ginger ability to low increased lipid parameters associated with diabetic complications. While, an increased oxidative stress has been shown to be increased in both insulin dependent diabetes. 
Table (6): Effect of different concentrations of cinnamon and ginger on the Low Density Lipoprotein (LDL) Levels $(\mathrm{mg} / \mathrm{dl})$ in the different diabetic rat groups.

\begin{tabular}{|c|c|c|c|c|c|c|c|c|c|}
\hline \multirow{3}{*}{$\sum^{\frac{n}{0}}$} & \multirow{2}{*}{$\begin{array}{l}\bar{\Xi} \\
\dot{\Xi} \\
\dot{\Xi}\end{array}$} & \multirow{2}{*}{ 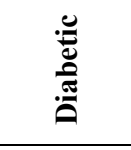 } & \multicolumn{2}{|c|}{ Cinnamon } & \multicolumn{2}{|c|}{ Ginger } & \multicolumn{2}{|c|}{$\begin{array}{c}\text { Cinnamon + } \\
\text { Ginger }\end{array}$} & \multirow[t]{2}{*}{ Drug } \\
\hline & & & $5 \%$ & $10 \%$ & $5 \%$ & $10 \%$ & $5 \%$ & $10 \%$ & \\
\hline & $\begin{array}{c}\text { Group } \\
1 \\
\end{array}$ & $\begin{array}{c}\text { Group } \\
2 \\
\end{array}$ & $\begin{array}{c}\text { Group } \\
\mathbf{3} \\
\end{array}$ & $\begin{array}{c}\text { Group } \\
4 \\
\end{array}$ & $\begin{array}{c}\text { Group } \\
5 \\
\end{array}$ & $\begin{array}{c}\text { Group } \\
6 \\
\end{array}$ & $\begin{array}{c}\text { Group } \\
7 \\
\end{array}$ & $\begin{array}{c}\text { Group } \\
8 \\
\end{array}$ & $\begin{array}{c}\text { Group } \\
9 \\
\end{array}$ \\
\hline 1 & $\begin{array}{c}78.70 p \\
\pm 1.23\end{array}$ & $\begin{array}{c}160.0 \mathrm{~d} \\
\pm 3.5\end{array}$ & $\begin{array}{c}\text { 157.0d } \\
\pm 4.1\end{array}$ & $\begin{array}{c}148.2 \mathrm{de} \\
\pm 2.1\end{array}$ & $\begin{array}{c}149.9 \mathrm{de} \\
\pm 3.2\end{array}$ & $\begin{array}{c}\text { 138.7hi } \\
\pm 2.1\end{array}$ & $\begin{array}{c}\text { 143.8gh } \\
\pm 2.3\end{array}$ & $\begin{array}{c}134.6 \mathrm{ij} \\
\pm 1.5\end{array}$ & $\begin{array}{c}109.7 \mathrm{~m} \\
\pm 0.8\end{array}$ \\
\hline 2 & $\begin{array}{c}79.80 p \\
\pm 2.3\end{array}$ & $\begin{array}{c}\text { 161.8d } \\
\pm 4.2\end{array}$ & $\begin{array}{c}153.4 \mathrm{~cd} \\
\pm 3.5\end{array}$ & $\begin{array}{c}146.3 \mathrm{efg} \\
\pm 3.3\end{array}$ & $\begin{array}{c}147.7 \mathrm{def} \\
\pm 5.1\end{array}$ & $\begin{array}{c}136.3 \mathrm{hij} \\
\pm 4.1\end{array}$ & $\begin{array}{c}145.0 \mathrm{efg} \\
\pm 4.4\end{array}$ & $\begin{array}{c}132.8 \mathrm{ijk} \\
\pm 4.7\end{array}$ & $\begin{array}{c}103.6 n \\
\pm 2.4\end{array}$ \\
\hline 3 & $\begin{array}{c}\text { 78.4op } \\
\pm 2.3\end{array}$ & $\begin{array}{c}167.2 \mathrm{~d} \\
\pm 3.1\end{array}$ & $\begin{array}{c}150.5 \mathrm{de} \\
\pm 1.6\end{array}$ & $\begin{array}{c}\text { 143.1ghi } \\
\pm 1.7\end{array}$ & $\begin{array}{c}144.2 \mathrm{ghi} \\
\pm 3.2\end{array}$ & $\begin{array}{c}132.6 \mathrm{ijk} \\
\pm 2.1\end{array}$ & $\begin{array}{c}140.3 \mathrm{ghi} \\
\pm 2.3\end{array}$ & $\begin{array}{c}127.5 \mathrm{jk} \\
\pm 2.6\end{array}$ & $\begin{array}{c}96.7 \mathrm{n} \\
\pm 3.1\end{array}$ \\
\hline 4 & $\begin{array}{c}77.0 \mathrm{p} \\
\pm 4.1\end{array}$ & $\begin{array}{c}175.9 \mathrm{c} \\
\pm 4.5\end{array}$ & $\begin{array}{c}149.9 \mathrm{de} \\
\pm 3.1\end{array}$ & $\begin{array}{c}\text { 141.2ghi } \\
\pm 3.6\end{array}$ & $\begin{array}{c}140.9 \mathrm{ghi} \\
\pm 5.3\end{array}$ & $\begin{array}{c}130.6 \mathrm{ijk} \\
\pm 4.0\end{array}$ & $\begin{array}{c}137.2 \mathrm{hij} \\
\pm 4.1\end{array}$ & $\begin{array}{c}123.8 \mathrm{kl} \\
\pm 4.1\end{array}$ & $\begin{array}{c}87.3 \text { no } \\
\pm 3.0\end{array}$ \\
\hline 5 & $\begin{array}{c}79.20 \mathrm{p} \\
\pm 1.23\end{array}$ & $\begin{array}{c}194.0 \mathrm{~b} \\
\pm 4.2\end{array}$ & $\begin{array}{c}147.2 \mathrm{e} \\
\pm 3.2\end{array}$ & $\begin{array}{c}138.4 \mathrm{hi} \\
\pm 1.5\end{array}$ & $\begin{array}{c}139.3 \mathrm{ghi} \\
\pm 1.2\end{array}$ & $\begin{array}{c}126.4 \mathrm{k} \\
\pm 1.8\end{array}$ & $\begin{array}{c}132.6 \mathrm{ijk} \\
\pm 2.1\end{array}$ & $\begin{array}{c}120.7 \mathrm{kl} \\
\pm 1.6\end{array}$ & $\begin{array}{c}79.5 o p \\
\pm 0.9\end{array}$ \\
\hline 6 & $\begin{array}{c}94.1 \mathrm{n} \\
\pm 8.2 \\
\end{array}$ & $\begin{array}{c}210.7 \mathrm{a} \\
\pm 6.0\end{array}$ & $\begin{array}{c}142.8 f g h \\
\pm 2.9 \\
\end{array}$ & $\begin{array}{c}\text { 136.6hij } \\
\pm 3.5\end{array}$ & $\begin{array}{c}137.3 \mathrm{hij} \\
\pm 4.4 \\
\end{array}$ & $\begin{array}{c}124.8 \mathrm{kl} \\
\pm 3.0\end{array}$ & $\begin{array}{c}128.8 \mathrm{jk} \\
\pm 3.9\end{array}$ & $\begin{array}{c}115.11 \\
\pm 3.7\end{array}$ & $\begin{array}{c}70.2 p \\
\pm 3.3\end{array}$ \\
\hline Mean & $81.20 \mathrm{H}$ & 178.27 A & 150.13 B & $142.40 \mathrm{C}$ & $143.22 \mathrm{C}$ & $\begin{array}{c}131.57 \\
\text { E }\end{array}$ & $\begin{array}{c}137.95 \\
\text { D }\end{array}$ & $\begin{array}{c}125.75 \\
F\end{array}$ & 91.17 G \\
\hline
\end{tabular}

Values are presented as mean $\pm \mathrm{SD}$

For each group of rats $\mathrm{n}=10$

S.E. Standard Error

Values followed by the same letter with in the same column were not significantly different

F-test group $(\mathrm{G})=(\mathrm{A}) 178.5^{* *} \mathrm{P}<0.01$

F-test weeks $(\mathrm{W})=(\mathrm{B}) 5.231^{* *} \mathrm{P}<0.01$

F-test $(\mathrm{G} \times \mathrm{W})=(\mathrm{AB}) 11.36^{* *} \mathrm{P}<0.01$

Effect of different concentrations of cinnamon and ginger on the Low Density Lipoprotein (LDL) Levels (mg/dl) in the different diabetic rat groups

The results given in the table (6) revealed that Low Density Lipoprotein (LDL) levels showed significant differences among all the nine studied groups, all feeding weeks as well as interaction between studied groups at $(\mathrm{p}<0.01)$. 
The results of the study showed that the mean LDL levels in diabetic rats groups treated with either cinnamon or ginger (3, 4, 5, 6, 7 and 8) recording $(150.13,142.40,143.22,131.57,137.95$, and $125.75 \mathrm{mg} / \mathrm{dl})$; respectively were significantly decreased as compared with diabetic groups (2) fed on basal diet without any treatment recording $178.27 \mathrm{mg} / \mathrm{dl}$. However, these levels were significantly increased than that of the control group of rats $(81.20 \mathrm{mg} / \mathrm{dl})$. While, group (9) standard fed on basal diet plus (Atorvastatin 10mg + Gliclagide 30mg) was recorded $91.17 \mathrm{mg} / \mathrm{dl}$ by the end of the feeding time of experiments (the $6^{\text {th }}$ week).

Ginger lowered the level of total cholesterol, TG, VLDL and LDL and improved the level of hyperlipidemic and diabetic rats these results were in agreement with those previously reported (Fuhrman et al., 2000 and Nicoll and Henein 2009) found that The adding ginger rhizome powder to the food could be useful in the management of cardiovascular disease in which atherosclerosis is the most important factor may be due to the presence poly-phenolic and flavonoids may prevent coronary artery disease by reducing plasma cholesterol level or by inhibiting LDL oxidation, a process which is through to play a key role in the pathogenesis of atherosclerosis. 
Table (7): Effect of different concentrations of cinnamon and ginger on the Very Low Density Lipoprotein (VLDL) levels (mg/dl) in the different diabetic rat groups.

\begin{tabular}{|c|c|c|c|c|c|c|c|c|c|}
\hline \multirow{4}{*}{$\frac{0}{\frac{0}{d}}$} & \multirow{2}{*}{ 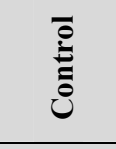 } & \multirow{2}{*}{$\begin{array}{l}.0 \\
\frac{0}{0} \\
\frac{0}{0} \\
\frac{\pi}{0}\end{array}$} & \multicolumn{2}{|c|}{ Cinnamon } & \multicolumn{2}{|c|}{ Ginger } & \multicolumn{2}{|c|}{$\begin{array}{c}\text { Cinnamon + } \\
\text { Ginger }\end{array}$} & \multirow[t]{2}{*}{ Drug } \\
\hline & & & $5 \%$ & $10 \%$ & $5 \%$ & $10 \%$ & $5 \%$ & $10 \%$ & \\
\hline & Group & Group & Group & Group & Group & Group & Group & Group & Group \\
\hline & 1 & 2 & 3 & 4 & 5 & 6 & 7 & 8 & 9 \\
\hline \multirow{2}{*}{1} & 22.000 & 45.90b & $44.1 b$ & $43.3 \mathrm{c}$ & $43.9 b$ & 42.1d & $39.2 \mathrm{~g}$ & 35.3hi & $29.9 \mathrm{kl}$ \\
\hline & \pm 0.91 & \pm 1.65 & \pm 1.13 & \pm 2.14 & \pm 2.12 & \pm 1.23 & \pm 1.46 & \pm 1.87 & \pm 1.35 \\
\hline \multirow{2}{*}{2} & 22.000 & $46.90 \mathrm{~b}$ & 42.70c & $40.10 d$ & $40.90 \mathrm{~cd}$ & 38.60de & 34.20hi & $30.80 j k$ & $27.60 \mathrm{klm}$ \\
\hline & \pm 0.83 & \pm 0.64 & $\pm \mathbf{0 . 8 2}$ & $\pm \mathbf{0 . 7 8}$ & $\pm \mathbf{0 . 8 2}$ & $\pm \mathbf{0 . 5 8}$ & \pm 1.16 & \pm 1.10 & $\pm \mathbf{0 . 7 5}$ \\
\hline \multirow{2}{*}{3} & 22.000 & $47.60 b$ & 41.20c & $39.70 d$ & $40.00 \mathrm{~d}$ & 37.60de & $30.90 \mathbf{j k l}$ & 28.10jk & $26.30 \mathrm{kIm}$ \\
\hline & \pm 0.79 & \pm 1.12 & \pm 1.32 & $\pm \mathbf{0 . 8 8}$ & \pm 0.99 & \pm 0.66 & \pm 0.78 & \pm 0.65 & \pm 0.69 \\
\hline \multirow{2}{*}{4} & 22.100 & 49.00ab & $40.30 \mathrm{~d}$ & 37.50ef & 38.50de & $36.00 \mathrm{fg}$ & 29.00jkl & $27.001 \mathrm{~m}$ & $25.70 \mathrm{mn}$ \\
\hline & \pm 1.35 & \pm 0.73 & \pm 0.76 & \pm 0.73 & \pm 0.72 & \pm 0.70 & \pm 1.54 & \pm 0.91 & $\pm \mathbf{0 . 6 7}$ \\
\hline \multirow{2}{*}{5} & 22.10 & $50.7 \mathrm{a}$ & 37.8ef & $36.2 \mathrm{fg}$ & $35.6 \mathrm{ef}$ & $32.8 \mathrm{~g}$ & $27.7 \mathrm{kl}$ & $25.4 \mathrm{mn}$ & $24.8 \mathrm{mn}$ \\
\hline & \pm 0.86 & \pm 1.13 & \pm 1.36 & \pm 1.16 & \pm 1.87 & \pm 1.54 & $\pm \mathbf{0 . 8 9}$ & \pm 1.56 & \pm 1.74 \\
\hline \multirow{2}{*}{6} & 22.100 & 51.10a & $31.60 \mathrm{ef}$ & 31.30h & $33.30 \mathrm{~g}$ & $29.90 i j$ & $24.50 \mathrm{~m}$ & 22.80no & 21.10o \\
\hline & \pm 1.35 & \pm 0.62 & \pm 0.69 & \pm 1.26 & $\pm \mathbf{0 . 8 9}$ & \pm 1.43 & \pm 1.38 & \pm 1.11 & \pm 0.69 \\
\hline Mean & $22.05 \mathrm{~F}$ & $49.20 \mathrm{~A}$ & 41.38 B & $38.68 \mathrm{C}$ & 40.90 B & $37.07 \mathrm{C}$ & 30.17 D & 26.67 E & $25.07 \mathrm{E}$ \\
\hline
\end{tabular}

Values are presented as mean $\pm \mathrm{SD}$
For each group of rats $n=10$
S.E. Standard Error

Values followed by the same letter with in the same column were not significantly different

F-test group $(\mathrm{G})=(\mathrm{A}) 231.5^{* *} \mathrm{P}<0.01$

F-test weeks $(\mathrm{W})=(\mathrm{B}) 63.5^{* *} \mathrm{P}<0.01$

F-test $(\mathrm{G} \times \mathrm{W})=(\mathrm{AB}) 7.12 * * \mathrm{P}<0.01$ 
= The Influence of Cinnamon and Ginger on Serum Glucose, Triglycerides and Cholesterol Fractions

Effect of different concentrations of cinnamon and ginger on the Very Low Density Lipoprotein (VLDL) levels (mg/dl) in the different diabetic rat groups

The results given in the table (7) revealed that Very Low Density Lipoprotein (VLDL) levels showed significant differences among all the nine studied groups, all feeding weeks as well as interaction between studied groups at $(\mathrm{p}<0.01)$.

The results of the study showed that the mean (VLDL) levels in diabetic rats groups treated with either cinnamon and ginger (3, 4, 5, 6, 7 and 8) recording $(41.38,38.68,40.90,37.07,30.17$ and $26.67 \mathrm{mg} / \mathrm{dl})$; respectively were significantly decreased as compared to diabetic group (2) fed on basal diet without any treatment recording $49.20 \mathrm{mg} / \mathrm{dl}$. However, these levels were significantly increased than that of the control group of rats $(22.05 \mathrm{mg} / \mathrm{dl})$. While, group (9) standard fed on basal diet plus (Atorvastatin $10 \mathrm{mg}+$ Gliclagide $30 \mathrm{mg}$ ) was recorded $25.07 \mathrm{mg} / \mathrm{dl}$ by the end of the feeding time of experiments (the $6^{\text {th }}$ week).

Cinnamon lowered the level of total cholesterol, TG, VLDL and LDL and improved the level of hyperlipidemic and diabetic rats. The observation of higher level of serum lipids in diabetic rats in many studies were found.

(Brahmachari, et al., 2009) mentioned that major compounds of cinnamon (cinnamaldehyde, cinnamyl acetate and cinnamyl alcohol) are converted into cinnamic acid by oxidation and hydrolysis, respectively. In the liver, cinnamic acid oxidized to benzoate that exists as sodium benzoate or benzoyl-CoA. Sodium benzoate was found to reduce the level of cholesterol in vivo in mice.

\section{Conclusion:}

In conclusion on the basis of above mentioned data. There were significant differences between untreated group and all other (8) studied groups of the experimental rats $(\mathrm{p}<0.01)$ in the serum glucose, serum triglycerides, total cholesterol, HDL cholesterol, LDL cholesterol and VLDL cholesterol. The best improvement on the serum glucose, triglycerides and cholesterol fractions 
in diabetic standard group was fed on basal diet plus (10 mg Atorvastatin +30 mg Gliclagide) followed by diabetic group was fed on basal diet plus $10 \%$ of both cinnamon and ginger then diabetic group was fed on basal diet plus $10 \%$ cinnamon and diabetic group was fed on basal diet plus $10 \%$ ginger.

\section{References}

- Abdulrazaq, N. B.; Cho, M. M.; Win, N. N.; Zaman, R. and Rahman, M. T. (2010): Beneficial effects of ginger (Zingiber officinale) on carbohydrate metabolism in streptozotocin induced diabetic rats. $\mathrm{Br} \mathrm{J}$. Nutr. 108: 1194-1201.

- Ali, B. H.; Blunden, G.; Tanira, M. O. and Nemmar, A. (2008): Some phytochemical, pharmacological and toxicological properties of ginger (Zingiber officinale Roscoe): Food Chem. Toxicol., Vol. 46: 409-420.

- Al-Jamal, A. and Rasheed, I. N. (2010): Effects of cinnamon (Cassia zelynicum) on diabetic rats. African J. of Food Sci.; 4 (9): 615-617.

- Allian, C. C.; Poon, L. S.; Chan, C. S. G. and Richmond, W. (1974): Enzymatic colourimetric method of the determination of plasma total cholesterol, Clin. Chem. 20:470.

- Amal, A.; Ibrahim, El. M. and Madkour, N. K. (2016): Insulin augmentation and glucagon inhibition in cinnamon treated diabetic rats. International Journal of Advanced Research, Volume 4, Issue 4, 1227 1235.

- Anderson, RA.; Broadhurst, C. L. and Polansky, M. M. (2006): Isolation and characterization of chalcone polymers from cinnamon with insulin like biological activities. Am. J. Clin. Nutr.; 84 (3): 1432-1436.

- Bairaktari, E. T.; Seferiadis, K. I. and Elisaf, M. (2005): Evaluation of methods for the measurement of low-density lipoprotein cholesterol. J. Cardiovasc Pharmacol Therapeut, 10: 45-54.

- Bhandari, U.; Sharma, J.N. and Zafar, R. $\left(\mathbf{1 9 9 8}^{\mathrm{b}}\right)$ : The protective action of ethanolic ginger (Zingiber officinale) extract in cholesterol-fed rabbits. J. Ethnopharmacol. 61:167-171.

- Brahmachari, S., Jana, A. and Pahan, K. (2009). Sodium benzoate, a metabolite of cinnamon and a food additive, reduces microglial and astroglial inflammatory responses. J. Immunol.; 183(9): 5917-5927. 
$=$ The Influence of Cinnamon and Ginger on Serum Glucose, Triglycerides and Cholesterol Fractions

- Broadhurst, C. L.; Polansky, M. M. and Anderson, RA. (2000). Insulin-like biological activity of culinary and medicinal plant aqueous extracts in vitro. J. of Agri. and Food Chem.; 48(3): 849-852.

- Castro, V.R. (1998): Chromium in series of Portuguese plants used in the herbal treatment of diabetes. Biological Trace Elements Research 62 (1-2), 101106.

- Chakraborty, D.; Mukherjee, A.; Sikdar, S.; Paul, A.; Ghosh, S. and Khuda Bukhsh A. R. (2012). 6-Gingerol isolated from ginger attenuates sodium arsenite induced oxidative stress and plays a corrective role in improving insulin signaling in mice, Toxicolo. Letters, vol. 210: 34- 43.

- Diaa and Al-Azhary (2011): Ginger Enhances Antioxidant Activity and Attenuates Atherogenesis in Diabetic Cholesterol-Fed Rats Australian Journal of Basic and Applied Sciences, 5(12): 2150-2158

- Duncan, B. D. (1955): Multiple range and multiple F test, Biometrics, 11 : 1-42.

- EL-Sayed, S. M. and Reham, A. (2016): Effect of Combined Administration of Ginger and Cinnamon on High Fat Diet induced Hyperlipidemia in Rats. Journal of Pharmaceutical, Chemical and Biological Sciences. P3 (4): 561-572.

- Elshater, A., A.; Salman, M. M. A. and Moussa, M. M. A. (2009): Effect of ginger extract consumption on levels of blood glucose, lipid profile and kidney functions in Alloxan induced-diabetic rats. J. Biolog. Sci. 2 (1): 153-162.

- Etuk, E. U. (2010): Animals model for studying diabetes mellitus. Agric. Biol. J. N. Am., 1(2): 130-134.

- Friedewald, W. T.; Levy, R. I. and Fredrickson, D. S. (1998): Determination of high density lipoprotein cholesterol by selective precipitation, Clin. Chem. 18:499-502. London.

- Fuhrman, B.; Rosenblat, M.; Hayek, T.; Coleman R. and Aviram, M. (2000). Ginger extract consumption reduces plasma cholesterol, inhibits LDL oxidation and attenuates development of atherosclerosis in atherosclerosis in atherosclerotic apolipo protein E-deficient mice. J. Nutr., 130(5): 1124-1131.

- Gandhi, G. R. and Sasikumar, P. (2012): Antidiabetic effect of Merremia emarginata Burm. F. in streptozotocin induced diabetic rats. Asian Pacific J. of 
Ropical Biomed., vol. 63: 281-286.

- Gazi, I.; Tsimihodimos, V.; Filippatos, T. D.; Saougos, V. G.; Bairaktari, E. T.; Tselepis, A. D. and Flisaf, M. (2006): LDL cholesterol estimation in patients with the metabolic syndrome, lipids in health and disease, 5:8.

- Goodman, L.S. and Gilman, A. (1985): The pharmacological basis of therapeutics. Macmillan, New York, pp.1490-1510.

- Gullapalli, H. S. M. D.; Avinash, P.; Tekade, MD.; Namrata. H.and Gullapalli, M. S. C. (2013): Effects of Consumption of Cinnamon on Blood Glucose and Lipid profile of the Patients of Type 2 Diabetes. Scholars Journal of Applied Medical Sciences (SJAMS) ISSN 2320-6691 .Sch. J. App.; 1(2): $28-32$.

- Hossain, M., and Islam, M. S. (2016): Comparative study of antihyperglycemic and antihypercholesteromic effect of aquous extract of Allium sativum (Garlic) and Zingiber officinale (Ginger) in alloxan induced rats. International Journal of Animal Resources, Volume-1, Number-1, January, Page 11 - 18.

- Hussein, M. A. A. (2012): The effect of ginger (Zingibar officinale) aqueous extract on some biochemical parameters and kidney function in male mice. M.Sc. Kufa Med. Journal. Vol.15. No.1.

- IDF (2011): International Diabetes Federation Diabetes atlas, $5^{\text {th }} \mathrm{Ed}$.

- Jafri, S. A.; Sohail, A. and Muhammad, Q. (2010): Hypoglycemic effect of ginger (Zingiber officinale) in alloxan induced diabetic rats, Pak. Vet. J. 31: 160- 162.

- Jiang, H.; Xie, Z.; Koo, H. J.; McLaughlin, S. P.; Timmermann, B. N. and Gan, D. R. (2006): Metabolic profiling and phylogenetic analysis of medicinal zingiberspecies: tools for authentication of ginger (Zingiber officinale Ros.). Phytochem., Vol. 67: 232-244.

- Kamble and Rambhimaiah (2013): Antidiabeticctivity of Aqueous Extract of Cinnamomum Cassia in Alloxan- Induced Diabetic Ratsbiomed. Andpharmacol. J., Vol. 6 (1), 83-88.

- Kar, A.; Choudhary, B.K. and Bandyopadhyay, N.G. (1999): Preliminary studies on the inorganic constituents of some indigenous hypoglycaemic herbs on oral glucose tolerance test. J. Ethnopharmacol. 64 (2): 179-184. 
- Khan, A.; Bryden N. A.; Polansky M. M. and Anderson, RA. (1990). Insulin potentiating factor and chromium content of selected foods and spices. Bio. Trace. Element Res.; 24(3): 183-188.

- Khan; Safdar, M.; Khan, M.; Khattak, K.and Anderson, R. (2003): Cinnamon improves glucose and lipids of people with type 2 diabetes: Diabetes Care, 26 (12), 3215-3218.

- Khandouzia, N.; Shidfar, F.; Rajab, A.; Rahideh,T.; Hosseini, P. and Taheri, M. (2015): The effects of ginger on fasting blood sugar, hemoglobinalc, apolipoprotein B,apolipoprotein a-I and malondialdehyde in type 2 diabetic patients. Iran J. Pharm Res. 131-140.

- Khogali, F. A. M.; Zamzami, S. A. F.; Jefrei, E. A.; Alsalmi, D. A.; Bahashwan, A. M. and Albukhari, A. A. (2014): Effect of Cinnamon Ameliorates on Blood Glocouse Level and Lipidemiaa mong Diabetic Patients. Journal of Medicine and Medical Research Vol. 2(2): 13 - 21, Febr uary.

- Kim, S.; Hyun, S. and Choung, S. (2006): Anti-diabetic effect of cinnamon extract on blood glucose in $\mathrm{db} / \mathrm{db}$ mice. Journal of Ethnopharmacology 104, 119-123.

- Li, Y.; Tran, V. H.; Duke, C. C. and Roufogalis, B. D. (2012): Gingerols of Zingiber officinale enhance glucose uptake by increasing cell surface GLUT4 in cultured L6 myotubes. Planta. Medica., vol. 78:1549-1555.

- Maisa, M. A; Qudah, Al.; Moawiya, A.; Haddad, J. M. F. and ELQudah. (2016): The effects of aqueous ginger extract on pancreas histology and on blood glucose in normal and alloxan monohydrateinduced diabetic rats. Biomedical Research; 27 (2): 350-356.

- Manal, L. K., and Anfenan (2014): Evaluation of Nutritional and Antidiabetic Activity of Different Forms of Ginger in Rats. Middle-East Journal of Scientific Research 21 (1): 56-62.

- Michigan State University (1983): MSTAT-C: Micro-Computers Statistical program, Version 2. Michigan State University, East Lansing.

- Muhamed, T.; Osman; Samir, H. and Ali (2016): Effect of Oral Cinnamon on Histological Damage Caused by Alloxan-Induced Diabetes Mellitus. Research Journal of armaceutical, Biological and Chemical Sciences.: 0975-8585.

- Nadia, M. T. A; Fathia, A. M. K. and Raafat, M. S. (2011). Therapeutic Effect 
of Onion (Allium cepa) and Cinnamon (Cinnamomum zeylanicum) oils on Cryptosporidiosis in Experimentally Infected Mice. Global Vet.; 7 (2): 179-183.

- Narendhirakannan, R. T.; Subramanian, S. and Kandaswamy, M. (2005): Mineral content of some medicinal plants used in the Lements Res., 103:109-115.

- Naserzadeh, Y. A.; Ilah Pouya, R. and Moien K. M. (2014): Effects of herb Cinnamon to control blood sugar and fat. Advances in Environmental Biology, 8 (13) August, Pages: 1119-1123.

- Nicoll, R. and Henein, M. Y. (2009): Ginger (Zingiber-officinale Roscoe): a hot remedy for cardiovascular disease. Int. J. ardiol., Vol.131:408-409.

- Pang, S. F.; Tang, F. and Tang, P. L. (1985): Alloxan induced diabetes and the pineal gland. Differential effects on the level of pineal N-acety L sserotonin, pineal. Melatonin and serum melatonin. J. pineal- Res., 2 (1):79-85.

- Ramudu, S. K.; Mllikarjuna, K. and Kesireddy, S. R. (2011) .Efficacy of ethanolic extract of ginger on kidney lipid metabolic profiles in diabetic rats, Int. J.Diabet. Dev. Ctries., vol. 31 (2): 97-103

- Reeves, P. G.; Nielsen, F. H. and Fahmy, G. C. (1993): Reported of the American Institute of Nutrition adhoc wriling committee on the reformulation of the AIN-76 Arodent diet. J. Nutr.; 123: 1939-1951.

- Shalaby and Samar, M. M. (2010). Effect of Zingiber officinale Roots and Cinnamon zeylanicum bark on Fertility of Male Diabetic Rats. Global Veter.; 5 (6): 341-347.

- Shen, Q.; Chen, F. and Luo, J. (2002): Comparison studies on chemical constituents of essential oil from Ramulu-scinnamomi and cortex cinnamomi by GC-MS. Zhong Yao Cai 25:257-258.

- Sniderman, A. D.; Blank, D.; Zakarian, R.; Bergeron, J. and Frahlich, J. (2003): Triglycerides and small dense LDL: the twin Achines heels of the friedeueld for mule. Clin. Biochem, (36): 499-504.

- Srinivasan, K. and Sambaiah, K. (1991): The effect of spices on cholesterol 7alpha hydroxylase activity and on serum and hepatic cholesterol levels in the rat. International Journal of Vitamins and Nutrition Research 61 (4): 364-369.

- Thomson, M.; Al-Qattan, K.; Khan, I.; Ali, M. and Al-Sawan, S. (2002): 
The use of ginger (Zingiber Officinale Rescoe) as a potential antiinflammatory and antithrombotic agent. Prostaglandins leukot. Essent. Fatty Acid., 76: 475-478.

- Trinder, P. (2000): Enzymatic determination of glucose in blood serum, Ann. Clin. Biochemist. 6:24 Iran.

- Ugochukw, N. H. and Babady, N. E. (2003). Antihyperglycemic effect of aqueous and ethanolic extract of Gongronema latifolium leaves on glucose and glycogen metabolism in liver of normal and streptozotocininduced diabetic rats. Life Sci.; 73: 1925-1938.

- Ugwuja, E. I.; Nwibo, A. N.; Ugwu, N. C. and Aloke, C. (2010): Effect of aqueous extract of spices mixture containing curry, garlic and ginger on plasma glucose and lipid in alloxan-induced diabetic rats. Pakist. J. of Nutr., 9 (12): 1131-1135.

- Verma, S. K; Singh, M.; Jain, P. and Bordia, A. (2004): Protective effect of Zingiber Officinale Roscoe on expermintal atherosclerosis in rabbits. Indian. J. Exp. Biol., 42: 736-738.

- Wahlefeld, A. W. (1974): In methods of enzymatic analysis, Vol.5, HU Berg Meyer, Ed. Academic Press, New York, pp. 1831-1835.

- Warnick, G. R.; Benderson, V. and Albers, N. (1983): Selected Methods Clin, Chem. 10: 91-99.

- White, B. (2007): Ginger: an overview. Am. Family Physici., vol. 75 (11): 1689-1691.

- WHO (2012): World Health Organizationfact sheet number 312, September 2012.

- Yajmk, C. S. (2001): The insulin resistance epidemic in India: fetal origins. Later Lifest, Nutr. Rev., 5: 1-9. 


\section{تأثير القرفة والزنجبيل على هستوى السكر والبليسريدات الثلاثية}

\section{وتجزؤات الدهون في فئران الألبينو المابة بالسكر}
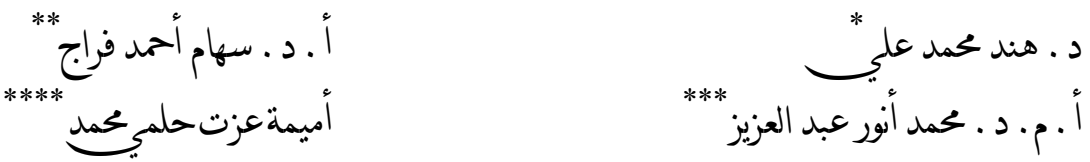

الملخص العربي

تنـاول البـحث دراسـة تأثير القرفـة والزنجبيـل على مستوى السكر والجليسـريدات الثلاثيـة

وتجزؤات الدهون على الفئران المصابة بالسكر.

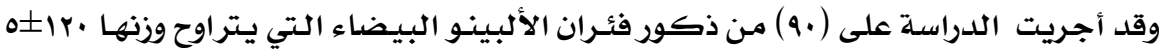

جرام حيث تم تقسيه الفئران إلى مجمـوعتين، المجموعة الأولى الضـابطة وتتكون مـن عشرة فئران تم

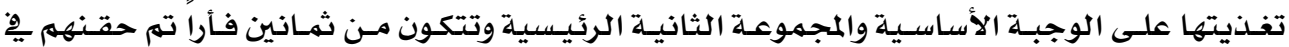
الغشاء البروتوني بجرعة الألوكسان ( •10 ملى جرام لكل كيلو جرام) من وزن الجسهم لكل فأر، كمها

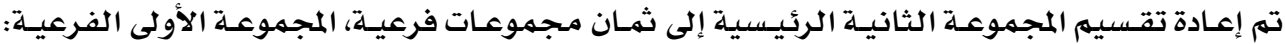

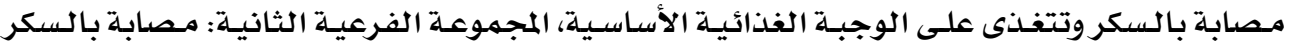
وتتغذى على الوجبة الغذائية الأسـاسية مضاف لها ه٪ مـ القرفة، المجموعـة الفرعيـة الثالثـة: مصابة بالسكر وتتغذىى على الوجبة الغذائية الأساسية مضاف لها ـ ا٪ من القرفة، المجموعة الفرعية الرابعة:

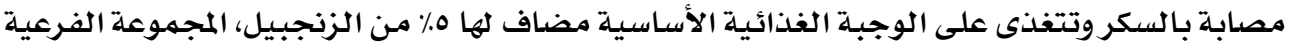

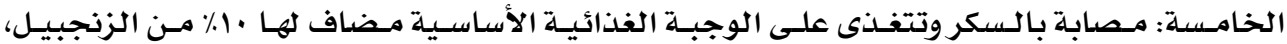

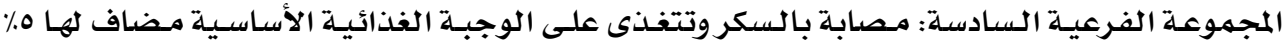
خليط كل من القرفـة والزنجبيل، المجموعة الفرعيـة السـابعة: مصـابة بالسكر وتتغـلى على الوجبــة

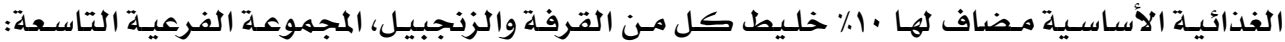

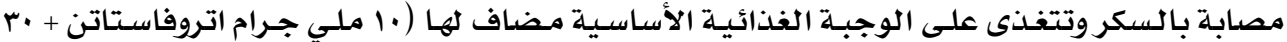

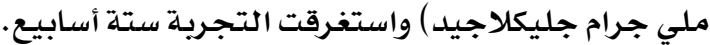
ويٌْ نهاية التجرية تم تجميع عينات الدم ثم فصل السيرم بجهاز الطرد المركزي.

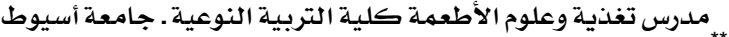

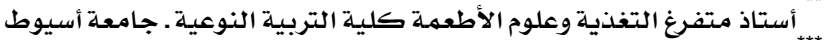

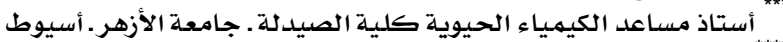

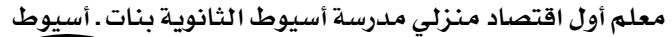




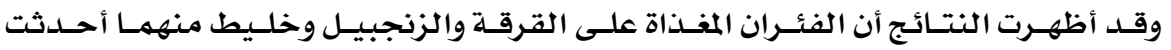
إنخفاضـاً معنويـا ِيْ سـكر الدم والكوليسترول الكلسي والجليسـريـات الثلاثيـة وكوليسترول البروتين منـخفض الكثافة وكوليسترول البروتين منخفض الكثافة جدا وزيادة يْ مستوى الكوليسترول مـرتفع الكثافـة وكـان أفضل تحسن يِ المجموعـة الفرعيـة الثامنسة المـصابة والمغـذاة على الوجبـة الغذائيسة الأسـاسيـة و (• ملـي جـرام اتروفاستاتن + ·r ملي جرام جليكلاجيد) وتليها المجموعة الفرعيـة السـابعة المصابـة والمغـذاة على الوجبـة الغذائيسة الأسـاسـية و · 1٪ مـن كـل مـن القرفة والزنجبيـل ثم المجمهوعـة

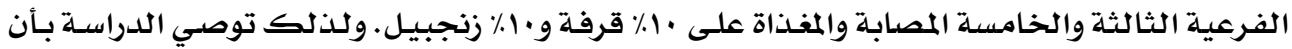
شـرب القرفة والزنجبيل يومياً تسـاعد على السيطرة على مـرض السـكر وتحسن مسستويات الجلوكوز وتجزؤات الدهون. الكلمات المفتاحية: القرفة ـ الزنجبيل ـ الفئران ـ سكر الدم ـ تجزؤات الدهون. 